\title{
PAFAH1B2 wt Allele
}

National Cancer Institute

\section{Source}

National Cancer Institute. PAFAH1B2 wt Allele. NCI Thesaurus. Code C97895.

Human PAFAH1B2 wild-type allele is located in the vicinity of $11 \mathrm{q} 23$ and is approximately $33 \mathrm{~kb}$ in length. This allele, which encodes platelet-activating factor acetylhydrolase IB subunit beta protein, plays a role in the metabolism of platelet-activating factor. 